Current Issues in Tourism

\title{
A bibliometric analysis of the presence of finances in high-impact tourism journals
}

\section{José Luis Jiménez-Caballero \& Silvia Polo Molina}

To cite this article: José Luis Jiménez-Caballero \& Silvia Polo Molina (2017) A bibliometric analysis of the presence of finances in high-impact tourism journals, Current Issues in Tourism, 20:3, 225-232, DOI: 10.1080/13683500.2016.1164674

To link to this article: http://dx.doi.org/10.1080/13683500.2016.1164674

曲 Published online: 24 Mar 2016.

Submit your article to this journal $\sqsubset x$

Џ Article views: 31

Q View related articles $\longleftarrow$

View Crossmark data ¿ 


\title{
RESEARCH LETTER
}

\section{A bibliometric analysis of the presence of finances in high-impact tourism journals}

\author{
José Luis Jiménez-Caballero* (D) and Silvia Polo Molina \\ Faculty of Tourism and Finance, University of Seville, Avda. San Francisco Javier s/n, 41018 \\ Seville, Spain
}

(Received 15 January 2016; accepted 7 March 2016)

\begin{abstract}
The purpose of this study is to observe the presence of financial research applied to tourism during the 1995-2012 period. The Scopus database has been used for tourism journals indexed in Journal Citation Reports and the Mendeley reference manager was used to manage the results. Two hundred and fifty-two articles were selected with basically financial content. The results reveal that in the majority of cases empirical research typology was used; the subject matter that aroused most interest was corporate finances and, within this, financial management, value creation, capital structure and investment decisions.
\end{abstract}

Keywords: finance; tourism; bibliometric analysis; Mendeley

\section{Introduction}

Vargas-Sánchez (2011) states that a tourism development model that does not feed off scientific research is inconceivable. One key area of research is finances. In this sense, the purpose of this study is to observe the presence of financial research and studies applied to tourism. An attempt will be made to achieve the goal that has been set using a bibliometric analysis and the observation of articles published in high-impact tourism journals, basically those indexed in the Web of Science Journal Citation Reports (JCR).

A number of specific objectives first have to be met to achieve this end goal:

- Research articles into finances published in JCR tourist journals have to be quantified.

- The temporal evolution of published articles must be ascertained (bearing in mind that the established time frame is from 1995 to 2012).

- The types of research carried out need to be known.

- The issues that have aroused the greatest interest among researchers over time, and those that have aroused little or no interest, need to be established.

We have chosen to study finances due to the importance of the field to cooperate in the development of the future management of tourism.

\section{Literature review}

Contreras Jiménez (2000) shows the importance and relevance of bibliometric studies in the field of science. There are also other authors who have conducted research studies and

*Corresponding author. Email: jjimenez@us.es 
investigations into bibliometric studies (Hall, 2005; Jamal, Smith, \& Watson, 2008; Jogaratnam, Chon, Mccleary, Mena, \& Yoo, 2005).

One example of categorisations of bibliometric studies is the study by Tsang and Hsu (2011), who classify these into three groups: (1) those that rank the contributions made by different authors or institutions in order; (2) those that analyse the methodologies and techniques used in tourism research; and (3) profile analyses that summarize published works, the topics covered and the places of publication. The present study would in broad terms fall into the third current.

Park, WooMi Jo, Deborah, and Abbott (2011) investigated publications in six of the main hospitality and tourism journals from 2000 to 2009 . The objective of the study was to ascertain what the main topics addressed in the field of tourism research were.

In relation to bibliometric studies in which the subject matter that intervened alongside tourism was finances, the study conducted by Law, Leung, and Cheung (2012) was based on a review of articles published in Cornell Hospitality Quarter. Tsai, Pan, and Lee (2011) conducted a bibliometric review that analysed the articles that contained aspects of financial management of tourism accommodation between 1998 and 2009 with similar characteristics to the study approached herein. However, they do not coincide as to the data source, or the analysed time frame, as our study covers a longer period.

\section{Methodology}

The five-phase methodology developed by Alfalla Luque, Marín García, and Medina López (2010) has been followed:

(1) Identification of field of study and period for analysis.

(2) Selection of information sources (Journals, Conference proceedings, Books, Theses and Internet).

(3) Perform search and pilot test:

- What? Search criteria.

- Where? Manual or db.

- How? Syntaxis.

(4) Management and purging of results:

- Selection of reference manager.

- Purging of results (classification, false positives and false negatives).

(5) Analysis of results.

The scope of the study is identified: finances in tourism. The choice of the study period (1995-2012) covers a broad period compared to other studies, and seeks significant results. Thomson and Reuters information website was visited and a search was conducted of JCR tourism journals. The search yielded $35 J C R$-rated hospitality and tourism journals, bearing in mind that the filter used was the terms Hospitality, Leisure, Sport and Tourism.

The acceptance criterion to identify articles was the selection of studies related to Finance or Tourism or related topics corresponding to the field of study. These criteria were then related to the following key words: corporate finance; financial markets; funding, financial resources, investment; mergers, acquisitions; corporate valuation; equity securities, fixed-income securities, securitisation, bonds, stocks securities; indebtedness/financial leverage; rating agencies; credit risk; stock exchange, stock exchange index; 
Table 1. Fields, areas and research topics in the financial domain.

\begin{tabular}{|c|c|c|c|c|c|}
\hline \multirow{2}{*}{$\begin{array}{l}\text { Research fields } \\
\text { Corporate or } \\
\text { business } \\
\text { finances }\end{array}$} & \multirow{2}{*}{$\frac{\text { Research areas }}{\text { Investment decisions }}$} & \multicolumn{4}{|c|}{ Research topics } \\
\hline & & Private investment in sectors & Financial return (investment) & $\begin{array}{l}\text { Net present value/ } \\
\text { internal rate of return }\end{array}$ & \\
\hline finances & $\begin{array}{l}\text { Capital structure and } \\
\text { dividend policy }\end{array}$ & Financial leverage & $\begin{array}{l}\text { Optimum financing } \\
\text { decisions }\end{array}$ & Dividends & \\
\hline & Corporate valuation & Fundamental analysis & $\begin{array}{l}\text { Valuation of tangible and } \\
\text { intangible assets }\end{array}$ & & \\
\hline & Value creation & Value creation for shareholders & $\begin{array}{l}\text { Indicators of value creation } \\
\text { (economic value added) }\end{array}$ & $\begin{array}{l}\text { Financial return (with } \\
\text { respect to a reference) }\end{array}$ & \\
\hline & $\begin{array}{l}\text { Property structure } \\
\text { Mergers and } \\
\text { acquisitions }\end{array}$ & Corporate governance & Agency problem & Property management & \\
\hline & Financial management & $\begin{array}{l}\text { Financial return: prices-costs/ } \\
\text { income-expense Yield } \\
\text { managements }\end{array}$ & $\begin{array}{l}\text { Solvency, liquidity and } \\
\text { credit risk }\end{array}$ & Financial planning & $\begin{array}{c}\text { Financial factors for } \\
\text { company growth }\end{array}$ \\
\hline \multirow[t]{6}{*}{ Financial markets } & $\begin{array}{l}\text { Efficient market } \\
\text { hypothesis }\end{array}$ & Financial anomalies & Fundamental analysis & Technical analysis & Behavioural finance \\
\hline & Portfolio decisions & Specific risk & Portfolio investments & & \\
\hline & Risk and return & Financial return & $\begin{array}{l}\text { Capital asset pricing model } \\
\text { and arbitrage pricing } \\
\text { theory }\end{array}$ & Stock return & \\
\hline & $\begin{array}{l}\text { Valuation of financial } \\
\text { assets }\end{array}$ & Valuation of derivatives & $\begin{array}{l}\text { Initial public offering, } \\
\text { takeover bid }\end{array}$ & & \\
\hline & $\begin{array}{l}\text { Market risk } \\
\text { management }\end{array}$ & Systematic risk & $\begin{array}{l}\text { Cover, speculation and } \\
\text { arbitration }\end{array}$ & & \\
\hline & Market information & Information asymmetries & Investor protection & & \\
\hline \multirow[t]{3}{*}{ Public finances } & $\begin{array}{l}\text { Public investment } \\
\text { Public funding }\end{array}$ & Sectoral investment & Aid to investment & & \\
\hline & Public budgets & Taxes & Public expenditure & & \\
\hline & $\begin{array}{l}\text { Fiscal and monetary } \\
\text { policy }\end{array}$ & Influence in financial markets & & & \\
\hline
\end{tabular}


Table 1. Continued.

\begin{tabular}{|c|c|c|c|c|}
\hline \multirow{2}{*}{ 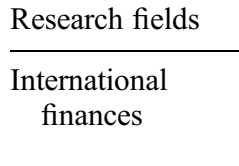 } & \multirow{2}{*}{$\begin{array}{c}\text { Research areas } \\
\text { International } \\
\text { investment and } \\
\text { development }\end{array}$} & \multicolumn{3}{|c|}{ Research topics } \\
\hline & & Direct foreign investment & Portfolio investment & Wealth effect \\
\hline & $\begin{array}{l}\text { Foreign currency } \\
\text { Sovereign debt } \\
\text { Financial crisis }\end{array}$ & Currency conversion risk & & \\
\hline Personal finances & $\begin{array}{l}\text { Personal income and } \\
\text { expenditure }\end{array}$ & Mortgages & & \\
\hline
\end{tabular}

Source: Prepared by authors. Adapted from Martín Marín (1995). 


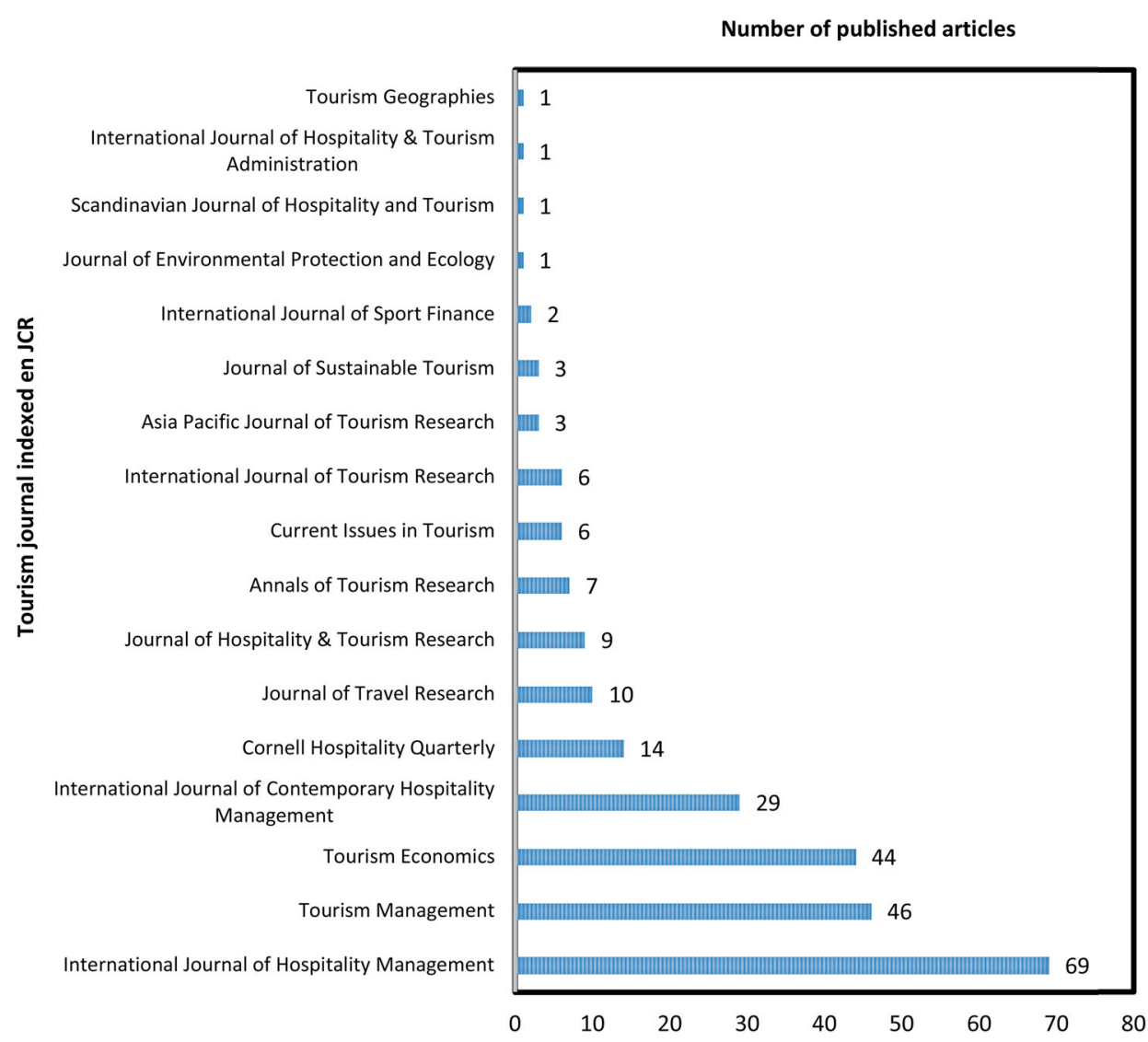

Figure 1. Production of financial articles by journal, 1995-2012.

banking, financial system, bank; derivatives markets, financial futures and options; financial return, ROI, ROE; systematic and specific risk, Sharpe, CAPM, beta; financial diversification, portfolio; country-risk, risk premium; working capital; suppliers, clients; cash flow, cash; cash management; collections and payments.

For this stage we chose 'Scopus' database. Once the desired result had been obtained it was necessary for these articles to be retrieved and exported to the Mendeley reference manager. The result obtained from this first examination was 1351 articles. They were purged with the result of 252 articles. Once the final number of articles had been obtained, a categorisation was established. Table 1 was used to sort the information.

\section{Results and discussion}

Between 1995 and 2012 tourism journals indexed in JCR produced 252 articles with strictly financial topics. It should be underscored that $81.3 \%$ of the articles were published during the second half of the analysed period (2004-2012), which means that tourism as a research topic, and, in this case, the financial aspect of tourism, has progressively gained interest in the scientific community.

Financial articles were found in 17 of the 35 journals indexed in JCR (Figure 1). Therefore, $48.57 \%$ of high-impact scientific journals in the sphere of tourism have published 
Table 2. Volume of articles by financial area and financial field of research during the 1995-2012 period.

\begin{tabular}{|c|c|c|c|c|c|c|c|c|c|c|c|c|c|c|c|c|c|c|c|}
\hline & 1995 & 1996 & 1997 & 1998 & 1999 & 2000 & 2001 & 2002 & 2003 & 2004 & 2005 & 2006 & 2007 & 2008 & 2009 & 2010 & 2011 & 2012 & Total \\
\hline Corporate finance & 2 & 4 & & 4 & 5 & 1 & 3 & 1 & 3 & 1 & 9 & 4 & 12 & 9 & 20 & 18 & 13 & 9 & 118 \\
\hline $\begin{array}{l}\text { Financial } \\
\text { management }\end{array}$ & & 1 & & 1 & & & 2 & 1 & 3 & & 3 & 1 & 5 & 5 & 7 & 6 & 7 & 1 & 43 \\
\hline Capital structure & & 1 & & 1 & 1 & 1 & & & & & 3 & 2 & 2 & 1 & 3 & 4 & & 1 & 20 \\
\hline $\begin{array}{l}\text { Investment } \\
\text { decisions }\end{array}$ & 2 & 1 & & & 2 & & & & & 1 & & & & 1 & 2 & & 3 & 1 & 13 \\
\hline Value creation & & & & 1 & 1 & & 1 & & & & 3 & 1 & 2 & 1 & 7 & 3 & 1 & 6 & 27 \\
\hline $\begin{array}{l}\text { Corporate } \\
\text { valuation }\end{array}$ & & 1 & & & & & & & & & & & 2 & & & 2 & 1 & & 6 \\
\hline Dividend policy & & & & & 1 & & & & & & & & 1 & & 1 & & & & 3 \\
\hline Property structure & & & & 1 & & & & & & & & & & 1 & & 3 & 1 & & 6 \\
\hline Financial markets & & & & 1 & & 2 & & 2 & 5 & 2 & 5 & 8 & 11 & 7 & 12 & 8 & 15 & 11 & 89 \\
\hline Market information & & & & & & 1 & & & & & & 2 & & & & & 1 & & 4 \\
\hline Portfolio decisions & & & & & & & & & & & & & & & 1 & 1 & & & 2 \\
\hline Risk and return & & & & 1 & & 1 & & 2 & 5 & 2 & 4 & 4 & 8 & 6 & 9 & 6 & 12 & 8 & 68 \\
\hline $\begin{array}{l}\text { Market risk } \\
\text { management }\end{array}$ & & & & & & & & & & & 1 & 1 & 3 & 1 & 2 & 1 & 2 & 2 & 13 \\
\hline $\begin{array}{l}\text { Efficient market } \\
\text { hypothesis }\end{array}$ & & & & & & & & & & & & 1 & & & & & & 1 & 2 \\
\hline $\begin{array}{l}\text { International } \\
\text { finance }\end{array}$ & & 1 & & & & 2 & & & 1 & 1 & 1 & 2 & 5 & & 2 & 5 & 4 & 1 & 26 \\
\hline $\begin{array}{l}\text { International } \\
\text { investment and } \\
\text { development }\end{array}$ & & 1 & & & & 2 & & & & 1 & 1 & 2 & 5 & & 1 & 2 & 3 & 1 & 19 \\
\hline Foreign currency & & & & & & & & & & & & & & & & 1 & 1 & & 2 \\
\hline Financial crisis & & & & & & 1 & & & 1 & & & & & & 1 & 2 & & & 5 \\
\hline Public finance & 1 & 2 & 3 & & 1 & 1 & 1 & & 1 & 1 & & 1 & & & & 3 & & 3 & 18 \\
\hline Public investment & 1 & 2 & 2 & & 1 & 1 & 1 & & 1 & 1 & & 1 & & & & 2 & & 3 & 16 \\
\hline Public funding & & & 1 & & & & & & & & & & & & & 1 & & & 2 \\
\hline Personal finance & & & & & & & & & & & 1 & & & & & & & & 1 \\
\hline $\begin{array}{l}\text { Personal income } \\
\text { and expenditure }\end{array}$ & & & & & & & & & & & 1 & & & & & & & & 1 \\
\hline Total & 3 & 7 & 3 & 5 & 6 & 6 & 4 & 3 & 10 & 6 & 15 & 15 & 28 & 16 & 34 & 34 & 32 & 25 & 252 \\
\hline
\end{tabular}


purely financial articles. The journals that contain the greatest financial production are International Journal of Hospitality Management (IJHM), Tourism Management (TM) and Tourism Economics (TE). These three together represent $63.09 \%$ of all financial articles published in hospitality and tourism journals.

In the selected articles, three different types of research can basically be observed: empirical, those that develop a model and theoretical. The majority of research has been empirical, with 185 articles ( $73.41 \%$ of the total).

Two research fields predominate: Corporate Finance and Financial Markets. The first of these has generated the highest number of publications, 118 in all, and the areas that obtain the highest number of articles are Financial Management, with 43, and Value Creation, with 27. Within the field of Financial Markets the area of Risk and Return predominates, with 68 related articles (Table 2).

\section{Conclusions}

Firstly, we can highlight that tourism as a research subject - and, in this case, with respect to its financial aspect - has gained interest among the scientific community during the 19952012 period. We therefore understand that the fact that financial research is gaining ever greater importance within tourism is, to a certain extent, the result of an increase in production that each of the disciplines has experienced separately.

The production of IJHM, TM and TE accounts for $63.09 \%$ of all financial articles published in hospitality and tourism journals during the study period. There is no relationship between a specific journal ranking JCR and the number of published articles.

With respect to the typology of the research undertaken, the majority of research in the field of finances related to tourism is empirical ( $73.41 \%$ of all research). The trend towards this type of research is also higher in bibliometric studies of finances.

The topic that arouses the greatest interest is Corporate Finance. This topic demonstrates how important the company is in the tourism phenomenon. Within this field Financial Management and Value Creation are the most addressed areas. The second most productive research field is Financial Markets and, within this, the area of Risk and Return. Other fields of importance, although of less interest, were International Finance and Public Finance. To conclude, only one article was detected that deals with Personal Finance, as a result of it is understood not generate sufficient interest to be addressed.

Given the importance of research into finances for improving business practice and public management, the contribution and significance of the findings for tourism policy and practice have been to detect the financial issues that concern the world of tourism today. Researchers should therefore be able to develop appropriate solutions from a financial point of view.

Lastly, one limitation of the study that can be highlighted is not knowing whether the financial research topics and issues that are of interest to professionals in the tourism sector are the same as those that are of concern to researchers.

\section{Disclosure statement}

No potential conflict of interest was reported by the authors.

\section{ORCID}

José Luis Jiménez-Caballero (D) http://orcid.org/0000-0003-3456-2960 


\section{References}

Alfalla Luque, R., Marín García, J. A., \& Medina López, C. (2010). Una propuesta metodológica para la realización de búsqueda sistemática de bibliografia [A methodological proposal for the realisation of systematic searches]. Working Papers on Operations Management, 1(2), 13-30.

Contreras Jiménez, E. (2000). Los métodos bibliométricos. Estado de la cuestión y aplicaciones [Bibliometric methods. State-of-the-art and applications]. Cuadernos de Documentación Multimedia, 10, 757-771.

Hall, C. M. (2005). Systems of surveillance and control: Commentary on 'An analysis of institutional contributors to three major academic tourism journals'. Tourism Management, 26(5), 653-656.

Jamal, T., Smith, B., \& Watson, E. (2008). Ranking, rating and scoring of tourism journals: Interdisciplinary challenges and innovations. Tourism Management, 29(1), 66-78.

Jogaratnam, G., Chon, K., Mccleary, K., Mena, M., \& Yoo, J. (2005). An analysis of institutional contributors to three major academic tourism journals: 1992-2001. Tourism Management, 26(5), 641-648.

Law, R., Leung, D., \& Cheung, C. (2012). A systematic review, analysis, and evaluation of research articles in the Cornell hospitality quarterly. Cornell Hospitality Quarterly, 53(4), 365-381.

Martín Marín, J. L. (1995). Perspectivas de la investigación en el campo de las finanzas en España [Perspectives of research in the field of finance in Spain]. Cuadernos Aragoneses de Economía, $5(2), 307-328$.

Park, K., WooMi Jo, P., Deborah, D. C., \& Abbott, J. (2011). Hospitality and tourism research rankings by author, university, and country using six major journals: The first decade of the new millennium. Journal of Hospitality and Tourism Research, 35(3), 381-416.

Tsai, H., Pan, S., \& Lee, J. (2011). Recent research in hospitality financial management. International Journal of Contemporary Hospitality Management, 23(7), 941-971.

Tsang, N., \& Hsu, C. (2011). Thirty years of research on tourism and hospitality management in china: A review and analysis of journal publications. International Journal of Hospitality Management, 30(4), 886-896.

Vargas-Sánchez, A. (2011). Los principales destinos son también las principales potencias en la investigación en turismo? [Are the main destinations also the major powers in tourism research?]. Estudios Turísticos, 188, 91-111. 